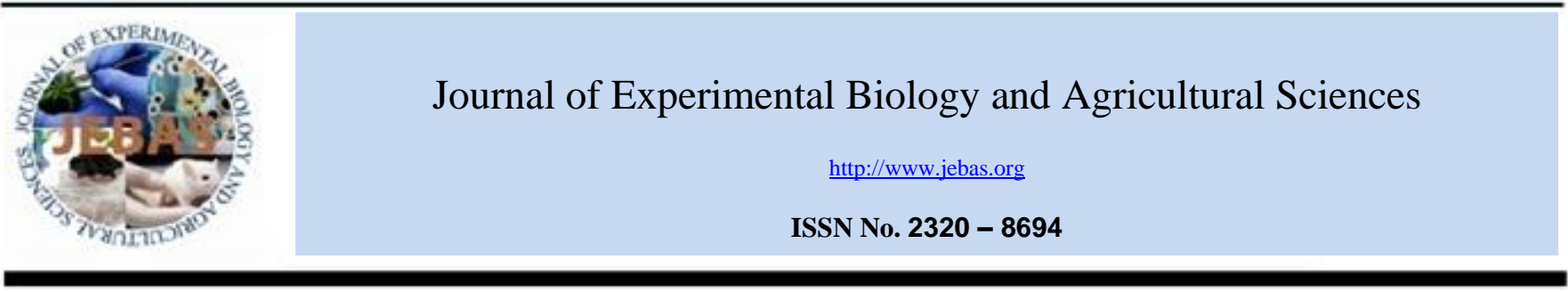

\title{
EMERGENCE OF EQUINE HERPES VIRUS 1 MYELOENCEPHALOPATHY: A BRIEF REVIEW
}

\author{
Baldev Raj Gulati ${ }^{1, *}$, Gayathri Anagha ${ }^{2}$, Thachamvally Riyesh ${ }^{1}$ and Sandip Kumar Khurana ${ }^{1}$ \\ ${ }^{1}$ ICAR-National Research Centre on Equines, Hisar, Haryana-125001, India \\ ${ }^{2}$ ICAR- Indian Veterinary Research Institute, Izatnagar, Bareilly, Uttar Pradesh-243122, India \\ Received - October 15, 2016; Revision - October 26, 2016; Accepted - November 20, 2016 \\ Available Online - December 04, 2016
}

DOI: http://dx.doi.org/10.18006/2016.4(Spl-4-EHIDZ).S132.S138

\begin{abstract}
KEYWORDS
Equine herpesvirus 1

Equine herpesvirus myeloencephalopathy

Neuropathogenicity

ORF30

ABSTRACT

Equine herpesvirus 1 (EHV1) is an economically important viral pathogen of equines and causes respiratory disease, neonatal foal mortality, late-term abortion and sporadic encephalomyelitis aka equine herpes myeloencephalopathy (EHM) in affected horses. The nervous form of EHV1 (EHM) has been recognized as early as 1950s in horse population; however, many aspects of this disease remained poorly understood. In recent years, there has been much progress in our understanding of genetics, epidemiology and pathogenesis of EHM through close monitoring of field outbreaks in different parts of the world. Various host, agent and environmental factors have been found to a play a role in the development of EHM, the most significant being the identification of a single nucleotide polymorphism in DNA polymerase gene $\left(A_{2254}\right.$ to $\left.G_{2254}\right)$, which imparts neuropathogenic potential to the virus. EHM affects horses of all ages, including un-weaned foals and produces clinical symptoms that are indistinguishable from other viral encephalitis/ central nervous system (CNS) disorders. EHM treatment includes supportive therapy, and reducing inflammation of CNS. Diagnosis of affected horses and monitoring of in-contact animals is the best measures to prevent EHM outbreaks. This review in brief discusses about progress made in epidemiology, pathogenesis, treatment, prevention and control of EHM.
\end{abstract}

\footnotetext{
* Corresponding author

E-mail: brgulati@gmail.com (Baldev R. Gulati)
}

Peer review under responsibility of Journal of Experimental Biology and Agricultural Sciences.

Production and Hosting by Horizon Publisher India [HPI] (http://www.horizonpublisherindia.in/).

All rights reserved.
All the article published by Journal of Experimental Biology and Agricultural Sciences is licensed under a Creative Commons Attribution-NonCommercial 4.0 International License Based on a work at www.jebas.org.

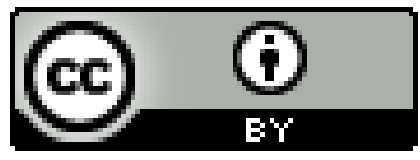




\section{Introduction}

Equine herpesvirus 1 (EHV1) is a highly contagious respiratory pathogen associated with a variety of disease conditions in horses. It is estimated that 80 to $90 \%$ of horses have been exposed to EHV1 infections by two years of age (Allen, 2008). EHV1 infection causes upper respiratory tract infection in young horses, abortion in pregnant mares, neonatal foal mortality and neurological disorders. Abortion is the most economically crippling outcome of EHV1 infection with 95\% of EHV1 associated abortions occurring in the last four months of pregnancy. Respiratory disease associated with EHV1 is most commonly seen in young animals at the time of weaning (Allen, 2008). Neurological disease associated with EHV1 is called equine herpesvirus myeloencephalopathy (EHM). Although clinical form of EHM is less frequently observed, it can cause serious economic losses in breeding horses and has very negative impact on equine industry (Friday et al., 2000; van Mannen et al., 2001; Henninger et al., 2007; Pronost et al., 2010).

During past decade, incidence of abortion and rhinopneumonitis due to EHV1 has been declining, possibly due to widespread vaccination practices. At the same time, there has been rise in incidence of EHM in many parts of world viz., Europe, North America, South America, Africa and Oceania (Perkins et al., 2009; Vissani et al., 2009; Pronost et al., 2010; Smith et al., 2010; Fritsche \& Borchers 2011; Tsujimura et al., 2011, Cuxson et al., 2014; Negussie et al., 2015; McFadden et al., 2016). The neuropathogenic strains of EHV1 (causing EHM) have also been reported from Asian countries such as Japan (Tsujimura et al., 2011) and India (Unpublished data). This article discusses the aetiology, pathogenesis, epidemiology of EHM and gives an overview of prevention, control and treatment of EHM.

\section{Etiology}

EHV1 is an enveloped, double-stranded DNA virus belonging to the genus Varicellovirus of the subfamily Alphaherpesvirinae within family Herpesviridae (Davison et al., 2009). As many as nine equine herpesviruses (EHV 1-9) species have been known to infect equines. Among these only five (viz., EHV1, 2, 3, 4 and 5) have the ability to produce diseases in horses. EHV3 is responsible for equine coital exanthema while EHV1 and 4 are the economically important viruses affecting the horses globally (Davison et al., 2009) with EHV1 capable of even causing abortion and neurological disorders as compared to EHV4 (Patel \& Heldens, 2005; Lunn et al., 2009). EHV2 and 5 do not cause any specific diseases but remain associated with upper respiratory tract diseases, immunosupression, general malaise and poor performance (Thein 1978; Belak et al., 1980).

EHV1 genome is $150 \mathrm{kbp}$ linear double-stranded DNA composed of a unique long region and unique short region flanked by inverted repeat regions, the terminal repeat and the internal repeat regions. The EHV-1 genome encodes for 76 open reading frames (ORFs). EHV1 isolates have special virulence markers, which are thought to induce EHM.

\section{Equine herpesvirus myeloencephalopathy}

EHM was present in equine population as early as 1950s, however, its importance came to limelight in the last decade after large outbreaks of EHM occurred in Europe and America (Perkins et al., 2009; Vissani et al., 2009; Pronost et al., 2010; Smith et al., 2010; Fritsche \& Borchers 2011; Pusterla et al., 2012; Damiani et al., 2014; Stasiak et al., 2015). Neurological disease can affect horses of all ages, including un-weaned foals, and often requires euthanasia of affected animal Horses exhibiting neurologic diseases can shed the virus in their nasal secretions and transmit the disease to in-contact animals (Henninger et al., 2007).)

The ORF30 spanning the nucleotide region 51522-55184 (3662 nt) in EHV1 genome encodes for a protein referred to as Pol, the putative DNA polymerase catalytic subunit which possesses DNA synthesis activity. This gene is highly conserved throughout its length. Recently, a single nucleotide polymorphism (SNP) of guanine (G) for adenine (A) at 2254 nucleotide position of the ORF30 region resulting in an amino acid variation, from asparagine to aspartic acid (N/D752) have been proven to be associated with the neuropathogenic potential of the EHV1 strain (Nugent et al., 2006). This DNA polymerase enzyme of EHV1 has two sets of identical protein subunits each of which contains two catalytic pockets (Liu et al., 2006), serving as site for polymerase activity and the site for 3'- 5' exonuclease activity. In EHV1, neuropathogenic strains, the point mutation results in a switch from no charge to a negative charge and induces a conformational change within the viral polymerase structure and thereby increases the replicative capacity of the virus and produce significantly higher viral loads (Nugent et al., 2006; Liu et al., 2006).

\section{Prevalence of neuropathogenicty}

Increased numbers of EHM cases have been reported from various parts of the world during the last decade with majority of them from Europe and North America. Europian countries viz., France (Pronost et al., 2010; van Galen et al., 2015), Germany (Fritsche \& Borchers, 2011; Damiani et al., 2014), Belgium (van der Meulen et al., 2003; Gryspeerdt et al., 2011), Poland (Stasiak et al., 2015), Netherlands (Goehring et al., 2006) and Croatia (Barbic et al., 2012); North American countries viz., Canada (Burgess et al., 2012) and U.S.A (Nugent et al., 2006; Henninger et al., 2007; Perkins et al., 2009; Smith et al., 2010; Pusterla et al., 2012); South American countries viz., Brazil (Mori et al., 2011) and Argentina (Vissani et al., 2009); Asian countries viz., Turkey (Yilmaz et al., 2012); Japan (Tsujimura et al., 2011) and India (Unpublished data); Islands viz ., Australia (Cuxson et al., 2014) and Newzealand (McFadden et al., 2016); African countries viz., Ethiopia (Negussie et al., 2015) experienced 
outbreaks of EHV1 infection by neuropathogenic strains of EHV1. The incidence of neuropathogenic genotype from cases of neurological illness reported from different countries varies between $20 \%$ and $86 \%$ (Perkins et al., 2009; Vissani et al., 2009; Pronost et al., 2010; Fritsche \& Borchers, 2011; Cuxson et al., 2014). The prevalence of neuropathogenic strains in abortion outbreaks varies between $1.5 \%$ and $25.8 \%$. The percentage prevalence was highest $(25.8 \%)$ in France (Pronost et al., 2010) followed by $19.4 \%$ in U.S.A (Smith et al., 2010), $10.6 \%$ in Germany (Fritsche \& Borchers, 2011), 7\% in Argentina (Vissani et al., 2009), 3.1\% in Poland (Stasiak et al., 2015), 2.7\% in Japan (Tsujimura et al., 2011) and $1.5 \%$ in Australia (Cuxson et al., 2014).

\section{Pathogenesis of EHM}

Upon entry into the animal body, virus multiplies in the epithelial cells of upper respiratory tract. Following initial replication, the virus spreads to the cells of lamina propria and underlying tissues within 12-24 h, after crossing the basement membrane. By 1-2 days post-infection (dpi), the virus reaches in the local lymph nodes draining the respiratory tract where further replication and infection of leukocytes occurs. Leukocytes harbouring the virus are released to the blood stream (Leukocyte-associated viremia) between 4-10 dpi which enables the virus to reach internal organs including CNS (Kydd et al., 1994; Gryspeerdt et al., 2011). Secondary replication occurs in endothelial cells of CNS-associated arterioles (in particular the vessels of the spinal cord), which may result in nervous system disorders 9-13 dpi. As a consequence, vasculitis, thrombosis, perivascular cuffing of lymphocytes at sites of endothelial infection occurs, probably caused by direct interaction of the host's immune system and infectious agent (Edington et al., 1986). This vascular damage leads to ischaemia and re-perfusion injury of the CNS. Neuropathogenic strains are capable of exhibiting longer and higher level viremia. This high level viremia, interfere the blood flow to CNS and resulting in development of neurological diseases (Fritsche \& Borchers, 2011). The exact mechanism by which leukocyte-associated viremia leads to myeloencephalopathy is not known.

\section{Clinical Signs of EHM}

Onset of clinical signs of EHM usually occur 6-10 dpi following the onset of viremia. Clinical signs depend on number and size of affected sites, as well as relevance and location of affected nervous tissue (caudal spinal cord is most affected). Clinical signs usually include fever, ataxia, paresis/paralysis of hind limbs, bladder dysfunction, urinary incontinence and sensory deficit in the perineal area. In addition ventral oedema, scrotal or preputial oedema in male horses, and limb oedema are also noticed. In severe cases of EHM, paralysis may advance to tetraplegia and death of animal is observed (van Mannen, 2002; Pusterla \& Hussey, 2014). EHM affected horse that remains in standing posture may have good prognosis. However, horses with severe neurologic disease may take more than a year for complete recovery, although some horses may be left with permanent neurologic sequalae.

\section{Factors affecting EHM}

Mechanism behind EHM is poorly understood. Studies on the evaluation of the risk factors associated with the development of EHM have been performed in Europe and in North America. Various factors viz., season, age, breed, sex, immunological status and latency have been found to be associated with EHM. A study in the Netherlands revealed a strong association between season and outbreaks of EHV neurological disease with all outbreaks occurring between mid-November and midMay. However, this season specificity has not been observed in all countries. Paillot et al. (2008) reported that neurological signs due to EHM were seen at an increased frequency in standard breeds, Hispanic breeds and draught breeds, with no cases of EHV-induced myeloencephalopathy in archetypical ponies, Haflinger, Fjord and Icelandic horses.

Experimental infection proved that older horses are more predisposed to the development of neurological disease as compared to young to young/middle aged horses. Adult horses may develop viremia 100 times higher than young horses and they are 8 times more likely to develop the disease (Allen, 2008). Latency by alpha herpes viruses is an important epidemiological strategy ensuring survival and spread within the natural host population (Whitley \& Gnann, 1993). EHV1 latency has been demonstrated in lymphoid as well as in neural tissues (Baxi et al., 1995; Borchers et al., 1999). Following reactivation, latently infected carriers may shed the virus in their nasal secretion and also may result in EHM following invasion of nervous system (Allen \& Timoney, 2007).

\section{Laboratory Diagnoses}

Laboratory diagnosis of EHM is currently based on at least one of the following criteria: clinical symptoms, cerebrospinal fluid examination, serological testing, virus isolation, molecular detection methods and post-mortem examination. Differential diagnosis should also be made from other viral cause of encephalitis, rabies, protozoal myeloencephalitis and non infectious conditions like neuritis of the cauda equina, central nervous system (CNS) trauma and different plant/chemical intoxications (Pusterla et al., 2009; Pusterla \& Hussey, 2014). Horses presented with clinical symptoms as explained elsewhere may be suspected for EHM. An increased protein concentration and albumin quotient may be noticed in CSF of affected horses.

Serological examination suggesting a 4-fold or greater increase in serum antibody titer between acute and convalescent samples in the clinically affected horses, along with antibodies in CSF, is strongly suggestive of EHM (Friday et al., 2000; van Maanen et al., 2001). However, many horses with EHM do not exhibit a 4-fold rise in $\mathrm{SN}$ titer, since the antibody titers rise rapidly and may have peaked by the time neurological signs appear (Friday et al., 2000; van Maanen et al., 2001). Virus 
isolation from nasal or nasopharyngeal swabs or buffy coat samples is considered as the 'gold standard' test for a laboratory diagnosis of EHV1 infection. However, EHM cases might not yield virus isolation, as virus shedding may stop by the time neurological signs appear (Pusterla et al., 2009).

Many of the published conventional PCR detection protocols (Ballagi- Pordany et al., 1990; Sharma et al., 1992; Wagner et al., 1992; Borchers \& Slater, 1993; Kirisawa et al., 1993; Lawrence et al., 1994., Wang et al., 2007) are unable to differentiate between neuropathogenic and nonneuropathogenic viruses. Hence, PCR assays based on ORF30 followed by sequence analysis can be used to differentiate neuropathogenic and non-neuropathogenic EHV1 isolates (Nugent et al., 2006; Allen, 2007; Leutenegger et al., 2008; Pusterla \& Hussey, 2014). Use of novel PCR platforms, such as real-time PCR assays based on ORF30 enable the differentiation of neuropathogenic and non-neuropathogenic viruses (Allen, 2007; Leutenegger et al., 2008). Single nucleotide polymorphism (SNP)-real-time PCR (Smith et al., 2012) and primer-probe energy transfer method (Malik et al., 2010) have been used for diagnosis of EHM. A SNP-based real-time PCR has been developed in our laboratory that is able to differentiate neuropathogenic and non-neuropathogenic EHV1 strains. Using this assay, we observed circulation of neuropathogenic EHV1 among Indian equine population (unpublished data).

\section{Treatment of EHM}

There is no specific treatment for EHM and the line of treatment is aimed at supportive medication to reduce CNS inflammation. Antiviral drugs for reducing viremia, nonsteroidal anti-inflammatory drugs (NSAID) for countering inflammation and anti-thrombotic drugs for preventing clot formation are commonly used for treatment (Lunn et al., 2009; Pusterla \& Hussey, 2014). Treatment with corticosteroids, such as prednisolone acetate or dexamethasone for 2 to 3 days, is frequently recommended for severely affected animals as their use could aid in reducing the incidence of vasculitis, thrombosis, and the resultant neural injury. Flunixin meglumine (nonsteroidal anti-inflammatory drug), which is commonly used for the treatment of CNS vasculitis can be used as these drugs suppress cellular interactions between infected lymphocytes and endothelial cells (Pusterla et al., 2009). Drugs like dimethyl sulfoxide, acetylsalicylic acid and pentoxifylline have also been used for thromboembolic events associated with vasculitis. Antiviral drugs such as acyclovir have been found effective in in-vitro studies, however, limited data is available on the in vivo efficacy of acyclovir. Administration of broad-spectrum antimicrobials is also found effective to combat the risk of development of cystitis in affected horses (Pusterla \& Hussey, 2014).

\section{Control of EHM}

There is no specific method for prevention and control of EHM. However, routine management practices aimed at reducing the likelihood of introduction and dissemination of EHV1 infection can prevent EHM in herd. The control measures are mainly focused around quarantine and vaccination (Lunn et al., 2009; Pusterla et al., 2009). Affected or suspected horses must be removed from the stable immediately and placed in strict isolation. Once EHV1 infection is confirmed, horses should remain in strict quarantine until they are fully recovered and are asymptomatic for 21 days. Horses from farms experiencing EHM infection should be maintained in their existing stable and segregated from other horses. There should be total movement restriction of animals from such farms (Pusterla et al., 2009; Pusterla \& Hussey, 2014). The currently used EHV1 vaccines are not able to provide protection against EHM. However, regular use of commercially available EHV1 vaccines enhances herd immunity, reduce viral shedding at the event of exposure and hence reduce EHM risk (Pusterla \& Hussey, 2014).

\section{Conclusions and future perspectives}

The development of neurological disease due to EHV1 infection is likely to be multi-factorial. Potential horse-specific risk factors for EHM include advanced age, breed, postexposure viraemic load, low cytotoxic-T lymphocyte precursors and environmental factors. Antemortem diagnosis of EHM relies mainly on real time-PCR detection of EHV1 in nasal secretions and blood. Although several vaccines are commercially available to prevent respiratory and abortigenic form of EHV1 infections, they do not provide protection from neurologic form of the disease. Even though there is a strong association between EHM and the $\mathrm{G}_{2254}$ mutation, this nucleotide substitution is not the only determinant of neurological disease. EHV1 isolates with $\mathrm{A}_{2254}$ genotypes have been associated with a number of cases of neurological disease. On the other hand, $\mathrm{G}_{2254}$ genotype EHV1 isolates have been recovered from horses with no evidence of neurological symptoms.

One of the possible reasons for this observation could be the fact that besides $A_{2254} \rightarrow G_{2254}$ substitution, other nonsynonymous nucleotide substitutions in ORF30 region can also have an effect on the production of neurological disease by either enhancing/attenuating the capability of viral replication rates in vivo. Furthermore, DNA polymerase is only one out of six proteins involved in 'elongation complex' of DNA replication machinery Substitutions occurring in the ORF of any one of these proteins could have a considerable impact on viral replication rates, which will in turn have an effect on neuropathogenicity.

This is an area of research that needs further investigation. Comparative whole genome sequencing of neuropathogenic EHV1 strains from different geographical location might decipher other markers related to neuropathogenicity. There is also need to understand the role of host factors in the pathogenesis of EHM, including host immunopathological mechanisms in response to EHV1 infection and latency. 


\section{Conflict of interest}

Authors would hereby like to declare that there is no conflict of interests that could possibly arise.

\section{References}

Allen GP (2007) Development of a real-time polymerase chain reaction assay for rapid diagnosis of neuropathogenic strains of equine herpesvirus-1. Journal of Veterinary Diagnostic Investigation 19: 69-72.

Allen GP, Timoney PJ (2007) Recent advances in our understanding of equine herpesvirus-1 (EHV-1) myeloencephalopathy. 107th Annual Meeting of the United States Animal Health Association, pp. 373-380.

Allen GP (2008) Risk factors for development of neurologic disease after experimental exposure to equine herpesvirus-1 in horses. American Journal of Veterinary Research 69: 15951600 .

Ballagi-Pordány A, Klingeborn B, Flensburg J, Belák S (1990) Equine herpesvirus type 1: detection of viral DNA sequences in aborted fetuses with the polymerase chain reaction. Veterinary Microbiology 22: 373-381.

Barbić L, Lojkić I, Stevanović V, Bedeković T, Starešina V, Lemo N, Lojkić M, Madić J (2012) Two outbreaks of neuropathogenic equine herpesvirus type 1 with breeddependent clinical signs. Veterinary Record 170:227.

Baxi MK, Efstathiou S, Lawrence G, Whalley JM, Slater JD, Field HJ (1995) The detection of latency associated transcripts of equine herpesvirus1 in ganglionic neurons. Journal of General Virology 76: 3113-3118.

Belák S, Pàlfi V, Tuboly S, Bartha L (1980) Passive immunization of foals to prevent respiratory disease caused by equine herpesvirus type 2. Entralbl Veterinarmed B 27: 826830.

Borchers K, Slater J (1993) A nested PCR for the detection and differentiation of EHV-1 and EHV-4. Journal of Virological Methods 45:331-336.

Borchers K, Wolfinger U, Ludwig H (1999) Latencyassociated transcripts of equine herpesvirus type 4 in trigeminal ganglia of naturally infected horses. Journal of General Virology 80: 2165- 2171.

Burgess BA, Tokateloff N, Manning S, Lohmann K, Lunn DP, Hussey SB, Morley PS (2012) Nasal shedding of equine herpesvirus-1 from horses in an outbreak of equine herpes myeloencephalopathy in Western Canada. Journal of Veterinary Internal Medicine 26:384-92.
Cuxson JL, Hartley CA, Ficorilli NP, Symes SJ, Devlin JM, Gilkerson JR (2014) Comparing the genetic diversity of ORF30 of Australian isolates of 3 equid alphaherpes viruses. Veterinary Microbiology 169:50-57.

Damiani AM, de Vries M, Reimers G, Winkler S, Osterrieder N (2014) A severe equine herpesvirus type 1 (EHV-1) abortion outbreak caused by a neuropathogenic strain at a breeding farm in northern Germany. Veterinary Microbiology 172:555-562.

Davison AJ, Eberle R, Ehlers B, Hayward GS, McGeoch DJ, Minson AC, Pellett PE, Roizman B, Studdert MJ, Thiry E (2009) The order Herpesvirales. Archives of Virology 154: 171-177.

Edington N, Bridges CG, Patel JR (1986) Endothelial cell infection and thrombosis in paralysis caused by equid herpesvirus-1: equine stroke. Archives of Virology 90:111-24.

Friday PA, Scarratt WK, Elvinger F, Timoney PJ, Bonda A (2000) Ataxia and paresis with equine herpesvirus type 1 infection in a herd of riding school horses. Journal of Veterinary Internal Medicine 14:197-201.

Fritsche AK, Borchers K (2011) Detection of neuropathogenic strains of Equid Herpesvirus 1 (EHV-1) associated with abortions in Germany. Veterinary Microbiology 147:176-180.

Goehring LS, van Winden SC, van Maanen C, Sloet van Oldruitenborgh-Oosterbaan MM (2006) Equine herpesvirus type 1-associated myeloencephalopathy in The Netherlands: a four-year retrospective study (1999-2003). Journal of Veterinary Internal Medicine 20:601-607.

Gryspeerdt A, Vandekerckhove A, Van Doorsselaere J, Van de Walle GR, Nauwynck HJ (2011) Description of an unusually large outbreak of nervous system disorders caused by equine herpesvirus 1 (EHV1) in 2009 in Belgium Vlaams Diergeneeskundig Tijdschrift 80:147-153.

Henninger RW, Reed SM, Saville WJ, Allen GP, Hass GF, Kohn CW, Sofaly C (2007) Outbreak of neurologic disease caused by equine herpesvirus-1 at a university equestrian center. Journal of Veterinary Internal Medicine 21:157-165.

Kirisawa R, Endo A, Iwai H, Kawakami Y (1993) Detection and identification of equine herpesvirus-1 and -4 by polymerase chain reaction. Veterinary Microbiology 36:57-67.

Kydd JH, Smith KC, Hannant D, Livesay GJ, Mumford JA (1994) Distribution of equid herpesvirus-1 (EHV-1) in respiratory tract associated lymphoid tissue: implications for cellular immunity. Equine Veterinary Journal 26:470-473.

Lawrence GL, Gilkerson J, Love DN, Sabine M, Whalley JM (1994) Rapid, single-step differentiation of equid herpesviruses 1 and 4 from clinical material using the polymerase chain 
reaction and virus-specific primers. Journal of Virological Methods 47:59-72.

Leutenegger CM, Madigan JE, Mapes S, Thao M, Estrada M, Pusterla N (2008) Detection of EHV-1 neuropathogenic strains using real-time PCR in the neural tissue of horses with myeloencephalopathy. Veterinary Record 162:688-690.

Liu S, Knafels JD, Chang JS, Waszak GA, Baldwin ET, Deibel MR Jr, Thomsen DR, Homa FL, Wells PA, Tory MC, Poorman RA, Gao H, Qiu X, Seddon AP (2006) Crystal structure of the herpes simplex virus 1 DNA polymerase. Journal of Biological Chemistry 281:18193-18200.

Lunn DP, Davis-Poynter N, Flaminio MJ, Horohov DW, Osterrieder K, Pusterla N, Townsend HG (2009) Equine herpesvirus-1 consensus statement. Journal of Veterinary Internal Medicine 23: 450-461.

Malik P, Pálfi V, Bálint A (2010) Development of a new primer-probe energy transfer method for the differentiation of neuropathogenic and non-neuropathogenic strains of equine herpesvirus-1. Journal of Virological Methods 169:425-427.

McFadden AM, Hanlon D, McKenzie RK, Gibson I, Bueno IM, Pulford DJ, Orr D, Dunowska M, Stanislawek WL, Spence RP, McDonald WL, Munro G, Mayhew IG (2016) The first reported outbreak of equine herpesvirus myeloencephalopathy in New Zealand. New Zealand Veterinary Journal 64:125-134.

Mori E, Borges AS, Delfiol DJ, Oliveira Filho JP, Gonçalves RC, Cagnini DQ, Lara MC, Cunha EM, Villalobos EM, Nassar AF, Castro AM, Brandao PE, Richtzenhain LJ (2011) First detection of the equine herpesvirus 1 neuropathogenic variant in Brazil. Revue scientifique et technique 30:949-954.

Negussie H, Gizaw D, Tessema TS, Nauwynck HJ (2015) Equine Herpesvirus-1 Myeloencephalopathy, an Emerging Threat of Working Equids in Ethiopia. Transboundary and Emerging Diseases doi: 10.1111/tbed.12377.

Nugent J, Birch-Machin I, Smith KC, Mumford JA, Swann Z, Newton JR, Bowden RJ, Allen GP, Davis-Poynter N (2006) Analysis of equid herpesvirus 1 strain variation reveals a point mutation of the DNA polymerase strongly associated with neuropathogenic versus nonneuropathogenic disease outbreaks. Journal of Virology 80:4047-4060.

Paillot R, Case R, Ross J, Newton R, Nugent J (2008) Equine Herpes Virus-1: Virus, Immunity and Vaccines. The Open Veterinary Science Journal 2: 68-91.

Patel JR, Heldens J (2005) Equine herpesviruses 1 (EHV-1) and 4 (EHV-4)-epidemiology, disease and immunoprophylaxis: a brief review. Veterinary Journal 170: 14-23.
Perkins GA, Goodman LB, Tsujimura K, Van de Walle GR, Kim SG, Dubovi EJ, Osterrieder N (2009) Investigation of the prevalence of neurologic equine herpes virus type 1 (EHV-1) in a 23-year retrospective analysis (1984-2007). Veterinary Microbiology 139:375-378.

Pronost S, Léon A, Legrand L, Fortier C, Miszczak F, Freymuth F, Fortier G (2010) Neuropathogenic and nonneuropathogenic variants of equine herpesvirus 1 in France. Veterinary Microbiology 145:329-333.

Pusterla N, David Wilson W, Madigan JE, Ferraro GL (2009) Equine herpesvirus-1 myeloencephalopathy: a review of recent developments. Veterinary Journal 180:279-289.

Pusterla N, Hussey GS (2014) Equine herpesvirus 1 myeloencephalopathy. Veterinary Clinics of North America: Equine Practice 30:489-506.

Pusterla N, Mapes S, Wademan C, White A, Estell K, Swain E (2012) Investigation of the role of mules as silent shedders of EHV-1 during an outbreak of EHV-1 myeloencephalopathy in California. Veterinary Record 170:465.

Sharma PC, Cullinane AA, Onions DE, Nicolson L (1992) Diagnosis of equid herpesviruses -1 and -4 by polymerase chain reaction. Equine Veterinary Journal 24:20-25.

Smith KL, Allen GP, Branscum AJ, Frank Cook R, Vickers ML, Timoney PJ, Balasuriya UB (2010) The increased prevalence of neuropathogenic strains of EHV-1 in equine abortions. Veterinary Microbiology 141:5-11.

Smith KL, Li Y, Breheny P, Cook RF, Henney PJ, Sells S, Pronost S, Lu Z, Crossley BM, Timoney PJ, Balasuriya UB (2012) New real-time PCR assay using allelic discrimination for detection and differentiation of equine herpesvirus-1 strains with A2254 and G2254 polymorphisms. Journal of Clinical Microbiology 50:1981-1988.

Stasiak K, Rola J, Ploszay G, Socha W, Zmudzinski JF (2015) Detection of the neuropathogenic variant of equine herpesvirus 1 associated with abortions in mares in Poland. BMC Veterinary Research 11:102.

Thein P (1978) The association of EHV-2 infection with keratitis and research on the occurrence of equine coital exanthema (EHV-3) of horses in Germany. In: Bryans JT, Gerber H (Eds) Equine infectious disease IV. Princeton New Jersey Veterinary Publications: 33-41.

Tsujimura K, Oyama T, Katayama Y, Muranaka M, Bannai H, Nemoto M, Yamanaka T, Kondo T, Kato M, Matsumura T (2011) Prevalence of equine herpesvirus type 1 strains of neuropathogenic genotype in a major breeding area of Japan. Journal of Veterinary Medical Science 73:1663-1667. 
van der Meulen K, Vercauteren G, Nauwynck H, Pensaert M (2003) A local epidemic of equine herpes virus-1 induced neurological disorders in Belgium. Vlaams Diergeneeskundig Tijdschrift 72: 366-372.

van Galen G, Leblond A, Tritz P, Martinelle L, Pronost S, Saegerman C (2015) A retrospective study on equine herpesvirus type-1 associated myeloencephalopathy in France (2008-2011). Veterinary Microbiology 179:304-309.

van Maanen C (2002) Equine herpesvirus 1 and 4 infections: an update. Veterinary Quarterly 24: 58-78.

van Maanen C, Sloet van Oldruitenborgh-Oosterbaan MM, Damen EA, Derksen AG (2001) Neurological disease associated with EHV-1-infection in a riding school: clinical and virological characteristics. Equine Veterinary Journal 33:191-196.

Vissani MA, Becerra ML, Olguín Perglione C, Tordoya MS, Miño S, Barrandeguy M (2009) Neuropathogenic and nonneuropathogenic genotypes of Equid Herpesvirus type 1 in Argentina. Veterinary Microbiology 139:361-364.
Wagner WN, Bogdan J, Haines D, Townsend HG, Misra V (1992) Detection of equine herpesvirus and differentiation of equine herpesvirus type 1 from type 4 by the polymerase chain reaction. Canadian Journal of Microbiology 38:1193-1196.

Wang L, Raidal SL, Pizzirani A, Wilcox GE (2007) Detection of respiratory herpesviruses in foals and adult horses determined by nested multiplex PCR. Veterinary Microbiology 121:18-28.

Whitley RJ, Gnann JW (1993) The epidemiology and clinical manifestations of herpes simplex virus infections. In Roizman B, Whitley RJ, Lopez C (Eds.) The Human Herpesviruses, New York: Raven Press: pp. 69-105.

Yilmaz H, Altan E, Turan N, Gurel A, Haktanir D, Sonmez K, Deniz S, Gulcubuk A, Gur E, Sonmez G, Richt AJ (2012) First Report on the Frequency and Molecular Detection of Neuropathogenic EHV-1 in Turkey Journal of Equine Veterinary Science 32: 525-530. 